Bull. Chem. Soc. Ethiop. 2017, 31(3), 491-498.

ISSN 1011-3924

(C) 2017 Chemical Society of Ethiopia and The Authors

Printed in Ethiopia

DOI: http://dx.doi.org/10.4314/bcse.v31i3.13

\title{
SYNTHESIS AND CHARACTERIZATION OF NOVEL SULFONAMIDES DERIVATIVES AND THEIR ANTIMICROBIAL, ANTIOXIDANT AND CYTOTOXICITY EVALUATION
}

\author{
Hajira Rehman ${ }^{1 *}$, Dr. Abdul Qadir ${ }^{1}$, Zulfiqar Ali ${ }^{2}$, Shahid Nazir ${ }^{3}$, Asmat Zahra ${ }^{1}$ and Tanzeela \\ Gulab Shahzady ${ }^{4}$ \\ ${ }^{1}$ Department of Chemistry, University of the Punjab, Lahore, Pakistan \\ ${ }^{2}$ Department of Basic Sciences \& Humanities, University of Engineering and Technology \\ Lahore KSK Campus, Pakistan \\ ${ }^{3}$ Department of Chemistry, Comsat Institute of Information \& Technology Riawind road \\ Lahore, Pakistan \\ ${ }^{4}$ Department of Chemistry, Lahore Garrison University, DHA phase VI Lahore, Pakistan
}

(Received February 20, 2016; Revised December 16, 2017; Accepted December 21, 2017)

\begin{abstract}
Five novel sulfonamides derivatives HR5-HR8 and HR14 were synthesized by sulfonylation of primary or secondary amine in the presence of base through nucleophilic substitution reaction. Structural elucidation was carried out through FT-IR, UV, ${ }^{1} \mathrm{H}$ NMR, MS and elemental analysis. Prepared compounds were evaluated against pathogenic strains of bacteria (S. aureus and E. coli) and fungi (A. flavous and A. nyger). Results were compared against standard antifungal and bacterial drug already available in market (isoconazole and sulfmethoxazole). It was found that compound HR14 showed good activity with MIC $1.5 \mu \mathrm{g} / \mathrm{mL}$ and $2.0 \mu \mathrm{g} / \mathrm{mL}$ for $S$. aurues and $E$. coli, respectively. While HR5 showed best antifungal activity with zone of inhibition 27.2+0.12 $\mathrm{mm}$ (MIC: $5.25 \mu \mathrm{g} / \mathrm{mL}$ ) and 18.1+0.12 $\mathrm{mm}$ (MIC: $12.5 \mu \mathrm{g} / \mathrm{mL}$ ) against A. flavous and A. nyger, respectively. Synthesized compounds were also tested for their in vitro antioxidant activity by using DDPH. Amongst all compounds HR5 was found to have potential activity with $15.60 \%$ antioxidant activity at $6 \mathrm{mM}$ concentration.
\end{abstract}

KEY WORDS: Sulfonamide, DPPH, AntiMICrobial activity

\section{INTRODUCTION}

Sulfonamides drugs have been used as preventive agents in chemotherapy against various diseases [1]. More than 30 drugs having sulfa drug as a functional group are in clinical use, such as antibacterial [2], antifungal [3], antiprotozoal [4], anti-inflammatory [5], and translational initiation inhibitors [6]. More recent use of sulfonamides are as an anticancer agent [7], antiviral HIV [8], and in Alzheimer's disease [9]. They are used effectively for the treatment of ulcerative colitis [10], urinary, intestinal and ophthalMIC infections and also for obesity [11]. Beside their vital role in human medicine they are also showing their promising importance in field of veterinary and agricultural sciences. Due to presence of $\mathrm{SO}_{2} \mathrm{NH}-$ group most important role of sulfonamide in medicinal field is as an antibacterial agent. Synthesis of bacterial DNA and RNA requires tetrahydrofolate as a co-factor, which is inhibited by sulfonamides, so production of new DNA and RNA dropped from lack of tetrahydrofolate which eventually decayed bacteria. Newer sulfonamides and their derivatives has obtained great attention in pharmaceutical field in order to compete life threatening issues caused by drug resistant strains of bacteria, i.e. Methicillin resistance as they have unusual ability of acclimatization against stress caused by antibiotics [12]. Disease causing organisms become much resistant when treated medically with routine antibiotic drug molecule, with appearance of additional species as per mutation, conjugation, transduction or transformation. So synthesis of new sulfonamides and

*Corresponding author. E-mail: aries_cute8@hotmail.com

This work is licensed under the Creative Commons Attribution 4.0 International License 
their derivatives have got more attention from researchers for its application in the field of medicine sciences and medical chemistry. In the present study five sulfonamide derivatives have been synthesized by the reaction of $p$-toluene sulfonyl chloride with $\mathrm{NH}_{2}$ group containing drugs such as ceftriaxone, cefepime, nicotinamide (vitamin B), cefadroxil, and nimsulide, respectively and their biological activities were evaluated by using bacterial and fungal strains such as Escherichia coli, Aspergillum niger and Aspergillum flavus.

\section{EXPERIMENTAL}

${ }^{1} \mathrm{H}$ NMR spectra were conducted on Bruker $400 \mathrm{MHz}$ spectrometer in DMSO- $d_{6}$ with tetramethylsilane as internal standard. MS data was recorded on Finnigan MAT 112 mass spectrometer. Elemental analysis was performed by using Perkin Elmer elemental analyzer. Melting points were taken on Gallenhamp MP Apparatus MP70. Infrared spectra were recorded on Cary 630 Agilent FT-IRin the range between 4000-600 $\mathrm{cm}^{-1}$. Absorption spectra were recorded by PGT90+ UV-Vis spectrophotometer.

\section{General procedure}

In this work efficient method based on Hinsberg test was used for preparation of sulphonamides, i.e. sulfonylation of primary or secondary amine in presence of base resulting in nucleophilic attack by amine. For sulfonylationtosyl chlorides were used [13] and base were used for neutralization of generated $\mathrm{HCl}$, i.e. pyridine in synthesis of sulfonylmethylamide [14]. In the present work base sodium carbonate was used for neutralization of $\mathrm{HCl}$. It was a one pot reaction, amine containing drug $(0.001 \mathrm{M})$ in water was stirred and $\mathrm{pH}$ was noted, then equimolar sulfonyl chloride was added and mixture was allowed to stirrer for 2 hours and $\mathrm{pH}$ was monitored. Precipitates were separated by filtration and were purified by preparatory thin layer chromatography.

Synthesis of (6R,7R)-7-((Z)-2-(methoxyimino)-2-(2-(4-methylphenylsulfonamido)thiazol-4yl)acetamido)-3-(((2-methyl-5,6-dioxo-1,2,5,6-tetrahydro-1,2,4-triazin-3-yl)thio)methyl)-8methylene-5-thia-1-azabicyclo[4.2.0]oct-2-ene-2-carboxylic acid (HR5)

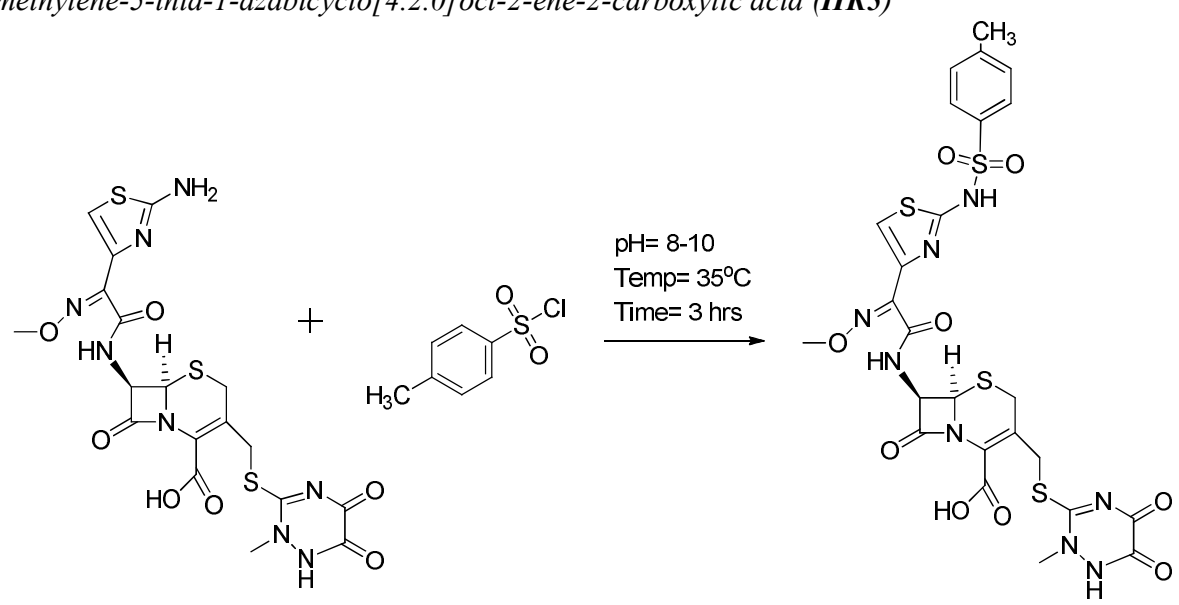

Title compound HR5 was prepared by above mentioned general procedure and was purified by using mobile phase DCM:EtOH, 50:50 with $83 \%$ yield. UV-Vis, $\lambda_{\max }: 270 \mathrm{~nm}$. FT-IR $\left(\mathrm{cm}^{-1}\right)$ :

Bull. Chem. Soc. Ethiop. 2017, 31(3) 
1178.19 ( $\mathrm{S}=\mathrm{O}$ str), 1037.18 (C-N str), $1633.80(\mathrm{C}=\mathrm{O}), 846.97$ (C-S str), 945.04 (S-N str), $3395.40(-\mathrm{OH}) .{ }^{1} \mathrm{H}$ NMR $\left(400 \mathrm{MHZ}, \mathrm{DMSO}-d_{6}, \delta\right): 11.22(1 \mathrm{H}, \mathrm{s},-\mathrm{COO} H), 8.36-8.47(1 \mathrm{H}, \mathrm{d}, J$

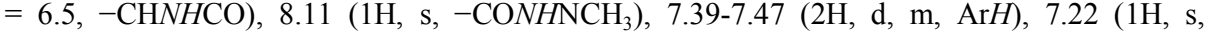
$-\mathrm{CHS}-)$, 7.05-7.11 (2H, m, $\operatorname{Ar} H), 5.68-5.76(1 \mathrm{H}, \mathrm{d}, J=6.3,-\mathrm{CHNHCO}-), 5.47-5.50(1 \mathrm{H}, \mathrm{d}, J$ $=1.2,-\mathrm{CH} H=\mathrm{CH}-), 5.12-5.23(1 \mathrm{H}, \mathrm{d}, J=6.2,-\mathrm{NCHS}-), 4.70-4.73(1 \mathrm{H}, \mathrm{d}, J=1.1$, $-\mathrm{CH} H=\mathrm{CH}-), 4.56\left(2 \mathrm{H}, \mathrm{s},-\mathrm{CH}_{2} \mathrm{SC}=\mathrm{N}-\right), 4.15\left(1 \mathrm{H}, \mathrm{s},-\mathrm{NHSO}_{2}-\right), 3.92\left(3 \mathrm{H}, \mathrm{s},-\mathrm{OCH}_{3}\right), 3.47-$ $3.56(1 \mathrm{H}, \mathrm{d}, J=6.5,-\mathrm{CHHS}-), 3.31\left(3 \mathrm{H}, \mathrm{s},-\mathrm{NCH}_{3}\right), 3.08-3.17(1 \mathrm{H}, \mathrm{d}, J=6.3,-\mathrm{CH} H \mathrm{~S}-), 2.49$ $\left.(3 \mathrm{H}, \mathrm{s},-\mathrm{ArCH})_{3}\right)$ MS (m/z, ESI): calcd. for $\mathrm{C}_{26} \mathrm{H}_{26} \mathrm{~N}_{8} \mathrm{O}_{8} \mathrm{~S}_{4}[\mathrm{M}+\mathrm{H}]^{+} 706.0210312$; found 706.0210615. Anal. calcd. For $\mathrm{C}_{26} \mathrm{H}_{26} \mathrm{~N}_{8} \mathrm{O}_{8} \mathrm{~S}_{4}$ : C, 42.36; H, 3.4; N, 15.81; O, 20.32; S, 18.10 . Found: C, 42.16; H, 3.46; N, 15.84; O, 20.17; S, 18.13 .

Synthesis of (6R,7R)-7-((Z)-2-(methoxyimino)-2-(2-(4-methylphenylsulfonamido)thiazol-4-yl) acetamido)-3-((1-methylpyrrolidin-1-ium-1-yl)methyl)-8-oxo-5-thia-1-azabicyclo[4.2.0]oct-2ene-2-carboxylate (HR6)

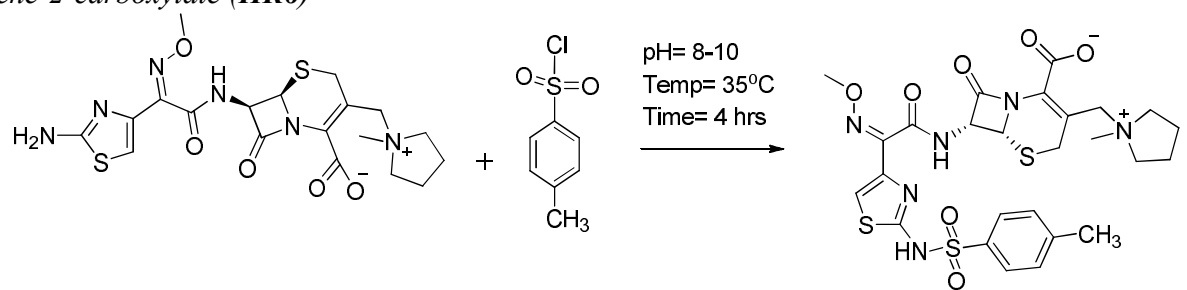

Designated compound HR6 was prepared by following the general procedure mentioned earlier and was purified by using mobile phase DCM:EtOH, 40:60. Compound was obtained with a good yield, 85\%. $\lambda_{\max } 280 \mathrm{~nm}$. FT-IR $\left(\mathrm{cm}^{-1}\right): 1158.15$ (S=O str), 1045.15 (C-Nstr), 1649.55 $(-\mathrm{N}-\mathrm{C}=\mathrm{O}), 825.38(\mathrm{C}-\mathrm{S}$ str $), 930.60(\mathrm{~S}-\mathrm{N}$ str $), 3378.15(-\mathrm{OH}) .{ }^{1} \mathrm{H}$ NMR $(400 \mathrm{MHZ}$, DMSO- $\left.d_{6}, \delta\right): 8.01-8.03(1 \mathrm{H}, \mathrm{d}, J=6.1,-\mathrm{CHNHCO}-), 7.62-7.65(2 \mathrm{H}, \mathrm{d}, J=8.3,-\mathrm{Ar} H), 7.44$ $(1 \mathrm{H}, \mathrm{s},-\mathrm{C}=\mathrm{CHS}-), 7.32-7.35(2 \mathrm{H}, \mathrm{d}, J=8.2,-\mathrm{Ar} H), 5.52-5.58\left(1 \mathrm{H}, \mathrm{d}, J=6.3,-\mathrm{NHCHCO}^{-}\right)$, 5.08-5.10 $(1 \mathrm{H}, \mathrm{d}, J=5.9,-\mathrm{SCHNCO}-), 4.28\left(1 \mathrm{H}, \mathrm{s},-\mathrm{NHSO}_{2}-\right), 4.01\left(3 \mathrm{H}, \mathrm{s},-\mathrm{OCH}_{3}\right), 3.81$ $\left(2 \mathrm{H}, \mathrm{s},-\mathrm{CH}_{2} \mathrm{NCH}_{3}\right), 3.61\left(1 \mathrm{H}, \mathrm{s},-\mathrm{CH}_{2} \mathrm{NCH}_{3}\right), 3.37-3.48\left(4 \mathrm{H}, \mathrm{t}, J=7.5, \mathrm{CH}_{3} \mathrm{NCH}_{2} \mathrm{CH}_{2}-\right), 3.20-$ $3.29(1 \mathrm{H}, \mathrm{d}, J=6.5,-\mathrm{CHHS}-), 3.07-3.14(1 \mathrm{H}, \mathrm{d}, J=6.4,-\mathrm{CH} H \mathrm{~S}-), 2.49\left(3 \mathrm{H}, \mathrm{s},-\mathrm{ArCH}_{3}\right), 1.44-$ $1.60\left(4 \mathrm{H}, \mathrm{Q}, J=6.9, \mathrm{CH}_{3} \mathrm{NCH}_{2} \mathrm{CH}_{2} \mathrm{CH}_{2}-\right)$; MS (m/z, ESI): calcd. for $\mathrm{C}_{26} \mathrm{H}_{30} \mathrm{~N}_{6} \mathrm{O}_{7} \mathrm{~S}_{3}[\mathrm{M}+\mathrm{H}]^{+}$ 634.1094327; found 634.0923741. Anal. calcd. for $\mathrm{C}_{26} \mathrm{H}_{30} \mathrm{~N}_{6} \mathrm{O}_{7} \mathrm{~S}_{3}$ : C, 49.20; H, 4.76; N, 13.24; O, 17.64; S, 15.5. Found: C, 49.35; H, 4.75; N, 13.23; O, 17.63; S, 15.16.

Synthesis of N-tosylnicotinamide (HR7)

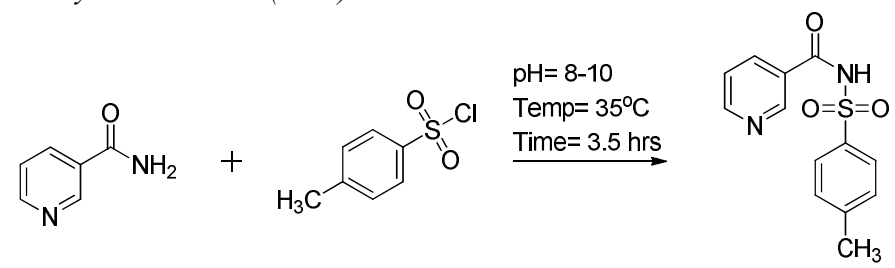

Following above mentioned procedure labeled compound HR7 was purified by using mobile phase DCM:EtOH, 60:40 having 76\% yield. $\lambda_{\max } 285 \mathrm{~nm}$. FT-IR $\left(\mathrm{cm}^{-1}\right): 1150.35(\mathrm{~S}=\mathrm{O} \mathrm{str})$, $1055.12\left(\mathrm{C}-\mathrm{N}\right.$ str), $1641.45(\mathrm{C}=\mathrm{O}), 815.32\left(\mathrm{C}-\mathrm{S}\right.$ str), $930.16(\mathrm{~S}-\mathrm{N}$ str $), 3388.12(-\mathrm{OH}) .{ }^{1} \mathrm{H}$ NMR (400 MHZ, DMSO- $\left.d_{6}, \delta\right): 9.24(1 \mathrm{H}, \mathrm{s},-\operatorname{ArH}), 8.84-8.88(1 \mathrm{H}, \mathrm{d}, \mathrm{J}=8.3,-\operatorname{ArH}), 8.51-8.54$ $(1 \mathrm{H}, \mathrm{d}, \mathrm{J}=8.2,-\mathrm{ArH}), 8.15\left(1 \mathrm{H}, \mathrm{s},-\mathrm{NHSO}_{2}-\right), 7.95-7.97(2 \mathrm{H}, \mathrm{d}, \mathrm{J}=8.1,-\mathrm{ArH}), 7.68-7.71$ $(1 \mathrm{H}, \mathrm{t}, \mathrm{J}=6.4,-\mathrm{ArH}), 7.40-7.42(2 \mathrm{H}, \mathrm{d}, \mathrm{J}=8.2,-\mathrm{ArH}), 2.33\left(3 \mathrm{H}, \mathrm{s},-\mathrm{ArCH}_{3}\right) . \mathrm{MS}(\mathrm{m} / \mathrm{z}, \mathrm{ESI})$ : calcd. For $\mathrm{C}_{13} \mathrm{H}_{12} \mathrm{~N}_{2} \mathrm{O}_{3} \mathrm{~S}[\mathrm{M}+\mathrm{H}]^{+}$276.5352716; found 276.573781. Anal. calcd. For 
$\mathrm{C}_{13} \mathrm{H}_{12} \mathrm{~N}_{2} \mathrm{O}_{3} \mathrm{~S}$ : C, 56.51; H, 4.38; N, 10.14; O, 17.37; S, 11.60. Found: C, 56.35; H, 4.41; N, $10.8 ; \mathrm{O}, 17.43 ; \mathrm{S}, 11.56$.

Synthesis of (6R,7R)-7-((R)-2-(4-hydroxyphenyl)-2-(4-methylphenylsulfonamido)acetamido)-3methyl-8-oxo-5-thia-1-azabicyclo[4.2.0]oct-3-ene-2-carboxylic acid (HR8)

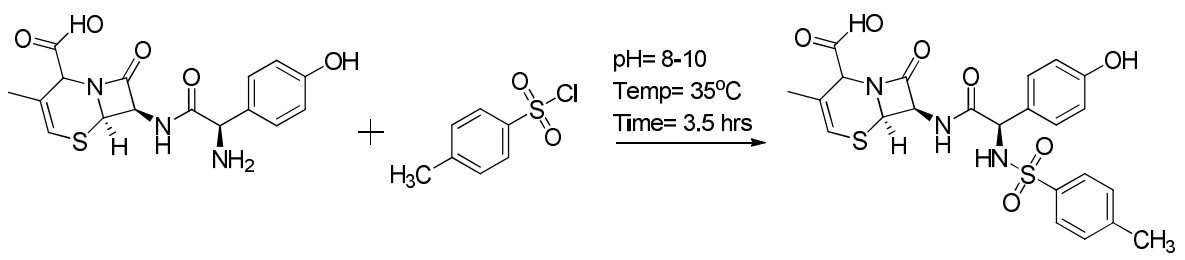

By following general procedure labeled compound $\mathbf{H R 8}$ was purified by using mobile phase DCM:EtOH, 80:20 having 87\% yield. $\lambda_{\max } 275 \mathrm{~nm}$. FT-IR $\left(\mathrm{cm}^{-1}\right): 1160.35$ (S=O str), 1053.12 $(\mathrm{C}-\mathrm{N}$ str $), 1647.45(\mathrm{C}=\mathrm{O}), 816.32(\mathrm{C}-\mathrm{S}$ str $), 940.16(\mathrm{~S}-\mathrm{N}$ str $), 3368.12(-\mathrm{OH}) .{ }^{1} \mathrm{H}$ NMR $(400$ MHZ, DMSO- $\left.d_{6}, \delta\right): 9.48(1 \mathrm{H}, \mathrm{s},-\mathrm{COOH}), 8.01-8.03(1 \mathrm{H}, \mathrm{d}, J=6.1,-\mathrm{CHNHCO}), 7.25-7.29$ $\left(1 \mathrm{H}, \mathrm{d}, J=6.2,-\mathrm{CHNHSO}_{2}\right), 6.98-7.17(4 \mathrm{H}, \mathrm{m},-\mathrm{Ar} H), 6.72-6.85(4 \mathrm{H}, \mathrm{m},-\mathrm{Ar} H), 6.27(1 \mathrm{H}, \mathrm{s}$, $-\mathrm{C}=\mathrm{CHS}-), 6.03(1 \mathrm{H}, \mathrm{s},-\mathrm{ArOH}), 5.57-5.72(1 \mathrm{H}, \mathrm{t}, J=7.1,-\mathrm{C} H \mathrm{NHCO}-), 5.06(1 \mathrm{H}$, $\mathrm{s},-\mathrm{NCHCOOH}), 4.84-4.86(1 \mathrm{H}, \mathrm{d}, J=6.4,-\mathrm{CHN}(\mathrm{S})), 4.78-4.82(1 \mathrm{H}, \mathrm{d}, J=6.3,-\mathrm{NHCHAr})$, $3.31\left(3 \mathrm{H}, \mathrm{s},-\mathrm{ArCH}_{3}\right), 2.49\left(3 \mathrm{H}, \mathrm{s}, \mathrm{CH}_{3} \mathrm{CH}=\mathrm{CH}-\right)$; MS (m/z, ESI): calcd. For $\mathrm{C}_{23} \mathrm{H}_{23} \mathrm{~N}_{3} \mathrm{O}_{7} \mathrm{~S}_{2}$ $[\mathrm{M}+\mathrm{H}]^{+}$517.5342617; found 517.5783681. Anal. calcd. For $\mathrm{C}_{23} \mathrm{H}_{23} \mathrm{~N}_{3} \mathrm{O}_{7} \mathrm{~S}_{2}$ : C, 53.37; H, 4.48; N, 8.12; O, 21.64; S, 12.39. Found: C, 53.35; H, 4.46; N, 8.14; O, 21.63; S, 12.36.

Synthesis of 4-methyl-N-(methylsulfonyl)-N-(4-nitro-2-phenoxyphenyl)benzenesulfonamide (HR14)
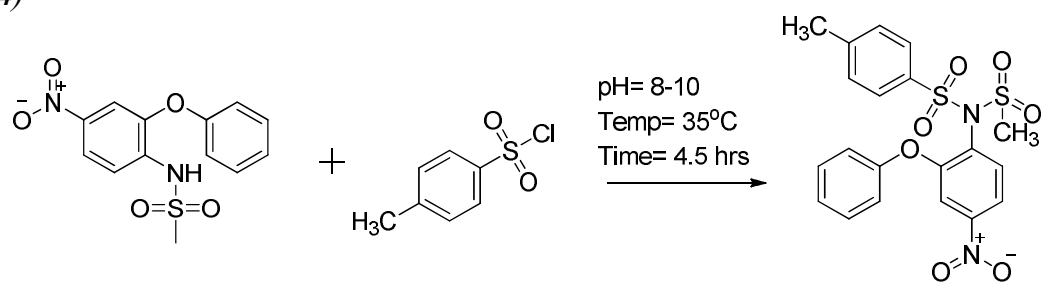

Labeled compound HR14 was synthesized by adopting above procedure in yield $56 \%$ and was purified by using mobile phase DCM: EtOH, 40:60. $\lambda_{\max } 290$. FT-IR $\left(\mathrm{cm}^{-1}\right): 1154.28$ ( $\mathrm{S}=\mathrm{O}$ str), 1079.40 (C-N str), $1595.70(\mathrm{C}=\mathrm{O}), 805.16\left(\mathrm{C}-\mathrm{S}\right.$ str), 975.07 ( $\mathrm{S}-\mathrm{N}$ str), $3761.15(-\mathrm{OH}) .{ }^{1} \mathrm{H}$ NMR (400 MHZ, DMSO- $\left.d_{6}, \delta\right): 7.69-7.72(4 \mathrm{H}, \mathrm{m},-\mathrm{ArH}), 7.39-7.43(4 \mathrm{H}, \mathrm{m},-\mathrm{ArH}), 7.12-7.14$ $(3 \mathrm{H}, \mathrm{d}, \mathrm{J}=8.1,-\mathrm{ArH}), 6.72-6.74(2 \mathrm{H}, \mathrm{d}, \mathrm{J}=8.2,-\mathrm{ArH}), 2.94\left(3 \mathrm{H}, \mathrm{s}, \mathrm{CH}_{3} \mathrm{SO}_{2}-\right), 2.35(3 \mathrm{H}, \mathrm{s}$, $-\mathrm{ArCH}_{3}$ ); MS (m/z, ESI): calcd. for $\mathrm{C}_{20} \mathrm{H}_{18} \mathrm{~N}_{2} \mathrm{O}_{7} \mathrm{~S}_{2}[\mathrm{M}+\mathrm{H}]^{+} 462.0362647$; found 462.753910. Anal. calcd. for $\mathrm{C}_{20} \mathrm{H}_{18} \mathrm{~N}_{2} \mathrm{O}_{7} \mathrm{~S}_{2}$ : C, 51.94; H, 3.92; N, 6.06; O, 24.22; S, 13.87. Found: C, 51.65; $\mathrm{H}, 3.86 ; \mathrm{N}, 6.10 ; \mathrm{O}, 24.23 ; \mathrm{S}, 13.76$.

\section{Antioxidant activity}

$D P P H$ radical scavenging assay. Using DDPH in vitro antioxidant activity of synthesized compounds was evaluated by a reported method [15]. All compounds were run in triplicate in order to produce precision of results. Trolox was used for standard curve. Using $\mathrm{R}^{2}$ value relative concentrations of compounds were determined, and scavenging $\%$, directly representing antioxidant activity, was determined using formula: Inhibition $\%=\left(1-\right.$ sample $\left._{530} / b l_{a n k} k_{530}\right) \times 100$. The results are given in Table 1 . 
Table 1. Antioxidant activity of sulfonamide derivatives HR5-HR8 and HR14.

\begin{tabular}{|c|c|c|}
\hline \multirow{2}{*}{ Compound } & \multicolumn{2}{|c|}{$\%$ antioxidant activity } \\
\cline { 2 - 3 } & $4 \mathrm{mM}$ & $6 \mathrm{mM}$ \\
\hline Trolox & 1.53 & 12.87 \\
\hline HR5 & 1.52 & 15.60. \\
\hline HR6 & 1.47 & 15.19 \\
\hline HR7 & 1.48 & 15.06 \\
\hline HR8 & 1.26 & 14.17 \\
\hline HR14 & 1.22 & 13.07 \\
\hline
\end{tabular}

\section{Biological activity}

Antibacterial activity. Growth media used was Luria-Bertain broth as it is highly efficient in bacterial growth [16]. Media was prepared using $4.0 \mathrm{~g}$ of tryptone, $2.0 \mathrm{~g}$ of yeast extract and 4.0 $\mathrm{g}$ of sodium chloride in $400 \mathrm{~mL}$ distilled water. Value of $\mathrm{pH}$ of media was maintained at 7.0. Above mentioned media was autoclaved at $125^{\circ} \mathrm{C}$ for $30 \mathrm{~min}$. Sample solutions were prepared in 5-50 $\mu \mathrm{g}$ concentration range. Three test tubes were labeled for each bacterial strain, i.e. $S$. aureus and E. coli. $2 \mathrm{~mL}$ of $\mathrm{LB}$ Broth and $20 \mu \mathrm{L}$ of bacterial strain were added in above sterilized tubes. After that stocks of 5, 10, and $20 \mu \mathrm{L}$ containing 5, 12.5, and $50 \mu \mathrm{g}$ were added in them. Then these tubes were incubated at $37{ }^{\circ} \mathrm{C}$ for 72 hours. After this OD of each medium and control medium were taken at $600 \mathrm{~nm}$. Graph was plotted between concentration and OD of compounds showing a comparative study for synthesized compounds (Table 2).

Table 2. Determination of MIC $\mu \mathrm{g} / \mathrm{mL}$ synthesized products against bacterial strains.

\begin{tabular}{|c|c|c|c|}
\hline S. No. & Name of compound & S. aureus & E. coli \\
\hline 1 & HR5 & 2 & 5 \\
\hline 2 & HR6 & 6.5 & 8.5 \\
\hline 3 & HR7 & 3 & 4.0 \\
\hline 4 & HR8 & 2.5 & 3.0 \\
\hline 5 & HR14 & 1.5 & 2.0 \\
\hline 6 & Sulfmethoxazole & 0.2 & 0.04 \\
\hline
\end{tabular}

Antifungal activity. Antifungal activity of compounds was evaluated by performing well diffusion test [17-21] using PDA (potato dextrose agar). A $24 \mathrm{~h}$ yeast culture of PDA was used to prepare inoculum. Sterile saline solution $(0.85 \%)$ was used for making suspension. Spectrophotometer was used to adjust turbidity of above suspension at $600 \mathrm{~nm}$ for getting final concentration matching with $0.5 \mathrm{McF}$ arland standard. Agar medium was autoclaved for $30 \mathrm{~min}$ at $120{ }^{\circ} \mathrm{C}$ then cooled at $50{ }^{\circ} \mathrm{C}$ and inoculated with $1 \mathrm{ml}$ of above suspension having absorbance $0.5 \mathrm{McF}$ arland. This inoculated medium were then poured into all assay plates $9 \mathrm{~cm}$ in diameter and were allowed to cool down until solidified. Upon solidification, equidistance four wells $6 \mathrm{~mm}$ in diameter were cut out of agar $6 \mu \mathrm{L}$ of medium was added into these wells having synthesized compounds. These plates were than incubated at $27{ }^{\circ} \mathrm{C}$ for $48 \mathrm{~h}$. MIC values in $\mu \mathrm{g} / \mathrm{mL}$ and zone of inhibition in $\mathrm{mm}$ were calculated for each compound, comparing it with standard antifungal isoconazol (ISC) in concentration $1.0 \mu \mathrm{g} / \mathrm{mL}$ in each plate as $+v e$ control. Results are given in Table 3 and 4.

Cytotoxicity test. In vitro, cytotoxicity test was performed using Vero cell line. Assay was based on protocol described by Borenfreund and Puerner (1984). 10\% FBS (Fetal Bovine Serum) containing Trypsin enzymes were used for cell growth in 96-well plates for 24 hours. After that $100 \mu \mathrm{L}$ of each sample and standard was loaded in above plate. MIC values were determined by comparison to doxorubicin hydrochloride as a reference drug. Two fold dilutions of test 
compounds and doxorubicin were prepared in ethanol $(1 \mathrm{~mL})$. Each dilute was finally added to media at room temperature giving a final concentration of $100,50,12.5 \mu \mathrm{g} \mathrm{mL}^{-1}$. This loaded plate was incubated for 48 hours at $37^{\circ} \mathrm{C}$, then natural red dye $10 \mu \mathrm{L}(40 \%)$ was introduced in all wells and incubated at same temperature for 4 hours. Then plate was washed two times with PBS and finally one time with acidified ethanol. Absorbance was recorded at $540 \mathrm{~nm}$ in a MICrotitre plate reader spectrophotometer. Activity of each well was found using given formula and is presented in Table 5. Cytotoxicity of sample $=(1$-Experimental well abs/ abs of negative control) x100.

Table 3. Determination of MIC $\mu \mathrm{g} / \mathrm{mL}$ products against fungal strains.

\begin{tabular}{|c|c|c|c|}
\hline S. No. & Name of compound & A.flavous & A. nyger \\
\hline 1 & HR5 & 5.25 & 12.5 \\
\hline 2 & HR6 & 8.50 & 14.5 \\
\hline 3 & HR7 & 12.5 & 30.0 \\
\hline 4 & HR8 & 50.0 & 65.5 \\
\hline 5 & HR14 & 7.50 & 13.0 \\
\hline 6 & Isoconazole & 0.50 & 0.76 \\
\hline
\end{tabular}

Table 4. Diameter of zone of inhibition $(\mathrm{mm} \pm \mathrm{SD})$.

\begin{tabular}{|c|c|c|c|}
\hline S. No. & Name of compound & A.flavous & A. nyger \\
\hline 1 & HR5 & $27.2 \pm 0.12$ & $18.1 \pm 0.12$ \\
\hline 2 & HR6 & $26.5 \pm 0.30$ & $16.3 \pm 0.33$ \\
\hline 3 & HR7 & $18.9 \pm 0.11$ & $14.9 \pm 0.22$ \\
\hline 4 & HR8 & $12.4 \pm 0.22$ & $10.6 \pm 0.10$ \\
\hline 5 & HR14 & $25.5 \pm 0.10$ & $17.1 \pm 0.11$ \\
\hline 6 & Isoconazole & 30 & 29.5 \\
\hline
\end{tabular}

Table 5. Cytotoxicity values of sulfonamide derivatives.

\begin{tabular}{|c|c|c|c|c|c|}
\hline \multirow{2}{*}{ Compound } & \multicolumn{2}{|l|}{ Absorbance } & \multicolumn{3}{|c|}{$\%$ Activity } \\
\hline & $\begin{array}{lll}100 & 50 & 1\end{array}$ & 12.5 & 100 & 50 & 12.5 \\
\hline HR5 & $0.89 \quad 0.90$ & 0.987 & 44 & 40 & 5.2 \\
\hline HR6 & $\begin{array}{lll}0.90 & 0.94 \\
\end{array}$ & 0.96 & 40 & 24 & 16 \\
\hline HR7 & $0.94 \quad 0.98$ & 0.99 & 24 & 8.0 & 4.0 \\
\hline HR8 & $0.94 \quad 0.97$ & 0.99 & 24 & 12 & 4.0 \\
\hline HR14 & $0.90 \quad 0.94 \quad 0$ & 0.99 & 40 & 24 & 4.0 \\
\hline Doxorubicin hydrochloride & $\begin{array}{lll}0.76 & 0.89 & 0 \\
\end{array}$ & 0.93 & 96 & 44 & 28 \\
\hline
\end{tabular}

\section{RESULT AND DISCUSSION}

A series of five sulfonamides were synthesized in aqueous basic media by simple reaction of five amino group containing drugs; ceftriaxone, cefepime, nicotinamide (vitamin B), cefadroxil and nimsulide with paratoluenesulphonyl chloride with continuous stirring and details of reaction conditions are explained in experimental section and synthetic pathway of sulfonamides is explained in general procedure. The compounds were obtained in good to excellent yield (55$87 \%$ ). Elemental analysis was performed for the conformation of all the compounds and measurement of absorption maximum $\left(\lambda_{\max }\right)$ provided the justification. The synthesized compounds were characterized by FT-IR; the characteristics band at $1148-1155.5 \mathrm{~cm}^{-1}$ of S=O stretching and $1048-1055 \mathrm{~cm}^{-1}$ for $(\mathrm{C}-\mathrm{N})$ and $813-814 \mathrm{~cm}^{-1}(\mathrm{C}-\mathrm{S})$ and $930-958.9 \mathrm{~cm}^{-1}$ (S-N) for all compounds reveals the formation of sulfonamides. Mass spectral data of all synthesized compounds was obtained by ESI-MS. The molar mass for compound HR5, $\mathrm{C}_{25} \mathrm{H}_{24} \mathrm{~N}_{8} \mathrm{O}_{9} \mathrm{~S}_{4}$, was originated as 708.77(calcd. 708.05). Correspondingly, observed mass for compound HR6, 
$\mathrm{C}_{26} \mathrm{H}_{30} \mathrm{~N}_{6} \mathrm{O}_{7} \mathrm{~S}_{3}$, was found as 634.13 (calcd. 634.75) and it proved the formation of the desired product. The prominent peaks for compounds, HR7 and HR8, were recorded at $\mathrm{m} / \mathrm{z} 122.05$ and 363.09 for stable fragments $\left[\mathrm{C}_{6} \mathrm{H}_{6} \mathrm{~N}_{2} \mathrm{O}\right]^{+},\left[\mathrm{C}_{16} \mathrm{H}_{17} \mathrm{~N}_{3} \mathrm{O}_{5} \mathrm{~S}\right]^{+}$, respectively. Observed and calcd molar masses of compounds HR7 and HR8 were found as 276.07 (calcd. 276.31), and 517.10 (calcd. 517.57), respectively. The major peak for compound HR14 was noticed at $\mathrm{m} / \mathrm{z} 462.06$ and showed good agreement with calculated molecular masses of concerned compound. The structures of all the compounds were also confirmed by ${ }^{1} \mathrm{H}$ NMR by dissolving in DMSO ${ }^{1} \mathrm{H}$ NMR spectra of compounds HR5-HR8, all $\mathrm{ArCH}_{3}$ showed their cheMICal shift values from 21.39 to $21.84 \mathrm{ppm}$, and found to be very much similar to the literature values. In HR5 and HR6 two methyl signals, i.e. $-\mathrm{NCH}_{3}$ and $-\mathrm{OCH}_{3}$ were also recorded at $38.65,60.21 \mathrm{ppm}$ and $50.39,63.99$, respectively. The cheMICal shift value of $-\mathrm{OCH}_{3}$ was observed on downfield side than $-\mathrm{NCH}_{3}$ due to strong electron withdrawing influence of oxygen than nitrogen. In HR7 a prominent peak of methyl $(\mathrm{C} 1)$ was noticed at $21.39 \mathrm{ppm}$. In this molecule there are two rings, one of them is attached with methyl and second ring contains nitrogen. In second ring cheMICal shift values of $\mathrm{C} 10, \mathrm{C} 12$ were found on downfield side due to electron withdrawing influence of nitrogen and peaks of $\mathrm{C} 2, \mathrm{C} 4$ were appeared on high field side due to the electron donating effect of $-\mathrm{CH}_{3}$ group. In $\mathbf{H R 8}$ a small peak was noticed at $174.17 \mathrm{ppm}$ due to carbon atom of $\mathrm{COOH}$ group.

Synthesized compounds were screened for their antibacterial and antifungal activities using sulfmethoxazole and isoconazol as reference antibacterial and antifungal agents. All developed compounds showed moderate to good activity for both bacterial and fungal strains but compound HR14 exhibited excellent activity against the E. coli and S. aureus (MIC 1.5 and 2.0) and compound HR5 showed good activity against A. Flavous and A. Nyger (MIC 5.25 and 12.5). Synthesized compounds were also screened for their antioxidant activity. Compound HR5 showed excellent and pronounced activity at $4 \mathrm{mM}$ concentration. The MIC values and zone of inhibitions are presented in Table 1-4. Cytotoxicity evaluation clearly shows that developed sulfonamides exhibited poor activity than standard drug, i.e. doxorubicin. Cytotoxicity values are presented in Table 5.

\section{CONCLUSION}

Five novel sulfonamides derivatives HR5-HR8 and HR14 were synthesized and evaluated for their antiMICrobial, antioxidant and cytotoxicity test. Most of the synthesized compounds showed promising antiMICrobial and antioxidant activity, suggesting a possible clinical significance of novel compounds. Compound HR14 showed remarkable antiMICrobial results, but compound HR5 was found to have potential antioxidant activity. However their cytotoxic effects are not so pronounced.

\section{ACKNOWLEDGEMENTS}

Author is highly thankful to HEC of Pakistan for financial support and extremely thankful to supervisor Dr. Abdul Qadir for his kind guidance. Finally author wishes her sincere gratitude to Institute of Chemistry, University of Punjab for providing lab facilities.

\section{REFERENCES}

1. Hansch, C.; Sammes, P.G.; Taylor, J.B. Comprehensive Medicinal Chemistry, Vol. 2, Pergamon Press: Oxford; 1990; chap. 7.1.

2. Kanda, Y.; Kawanishi, Y.; Oda, K.; Sakata, T.; Mihara, S.; Asakura, K.; Kanemasa, T.; Ninomiya, M.; Fujimoto, M.; Kanoike, T. Synthesis and structure-activity relationships of potent and orally active sulfonamide ETB selective antagonists. Bioorg. Med. Chem. 2001, 9, 897-907.

3. Stokes, S.S.; Albert, R.; Buurman, Ed.T.; Andrews, B.; Shapiro, A.B.; Green, O.M.; McKenzie, A.R.; Otterbein, L.R. Inhibitors of the acetyltransferase domain of N- 
acetylglucosamine-1-phosphate-uridylyltransferase/glucosamine-1-phosphate acetyltransferase $(\mathrm{GlmU})$. Part 2: Optimization of physical properties leading to antibacterial aryl sulfonamides. Bioorg. Med. Chem. Lett. 2012, 22, 7019-7023.

4. Chibale, K.; Haupt, H.; Kendrick, H.; Yardley, V.; Saravanamuthu, A.; Fairlamb, A.H.; Croft, S.L. Antiprotozoal and cytotoxicity evaluation of sulfonamide and urea analogues of quinacrine. Bioorg. Med. Chem. Lett. 2001, 11, 2655-2657.

5. Rahavi Ezabadi, I.; Camoutsis, C.; Zoumpoulakis, P.; Geronikaki, A.; Soković, M.; Glamočilija, J.; Čirič, A. Sulfonamide-1,2,4-triazole derivatives as antifungal and antibacterial agents: Synthesis, biological evaluation, lipophilicity, and conformational studies. Bioorg. Med. Chem. 2008, 16, 1150-1161.

6. Kennedy, J.F.; Thorley, M. Pharmaceutical Substances, 3rd ed., Kleeman, A.; Engel, J.; Kutscher, B.; Reichert, D. (Eds.), Thieme: Stuttgart; 1999.

7. Serradeil-Le Gal, C. An overview of SR121463, a selective non-peptide vasopressin V2 receptor antagonist. Cardiovascular Drug Rev. 2001, 19, 201-214.

8. Natarajan, A.; Guo, Y.; Harbinski, F.; Fan, Y.-H.; Chen, H.; Luus, L.; Diercks, J.; Aktas, H.; Chorev, M.; Halperin, J.A. Novel arylsulfoanilide-oxindole hybrid as an anticancer agent that inhibits translation initiation. J. Med. Chem. 2004, 47, 4979-4982.

9. Vullo, D.; De Luca, V.; Scozzafava, A.; Carginale, V.; Rossi, M.; Supuran, C.T.; Capasso, C. The extremo- $\alpha$-carbonic anhydrase from the Thermophilic bacterium Sulfurihydrogenibiumazorense is highly inhibited by sulfonamides. Bioorg. Med. Chem. 2013, 21, 4521-4525.

10. Wilson, C.O.; Gisvold, O.; Block, J.H. Wilson and Gisvold's Textbook of Organic Medicinal and Pharmaceutical Chemistry, 11th ed., Block, J.; Beale, J.M. (Eds.), Lippincott Williams and Wilkins: Philadelphia; 2004.

11. Levin, J.I.; Chen, J.M.; Du, M.T.; Nelson, F.C.; Killar, L.M.; Skala, S.; Sung, A.; Jin, G.; Cowling, R.; Barone, D.; March, C.J.; Mohler, K.M.; Black, R.A.; Skotnicki, J.S. Anthranilate sulfonamide hydroxamate TACE inhibitors. Part 2: SAR of the acetylenic P1' group. Bioorg. Med. Chem. Lett. 2002, 12, 1199-1202.

12. Livermore, D.M. Antibiotics resistance in staphylococci. Int. J. Antimicrobiol. Agents 2000, $16,3-10$.

13. Whitaker, D.T.; Whitaker, K.S.; Johnson, C.R.; Haas, J. p-Toluenesulfonyl Chloride. Encyclopedia of Reagents for Organic Synthesis. John Wiley and Sons: New York; 2006; DOI: 10.1002/047084289X.rt136.pub2.

14. Online Publication, Working with hazardous chemicals. Organic Syntheses, Coll. Vol. 4, p. 943 (1963); Vol. 34, p. 96 (1954). DOI:10.15227/orgsyn.034.0096.

15. Mohammed, H. Natural and synthetic flavonoid derivatives with potential antioxidant and anticancer activities. PhD Dissertation, Chemie, Pharmazie, Bio- und Werkstoffwissenschaften der Universität des Saarlandes, Saarbrücken, Germany, 2009.

16. Sezonov, G.; Joseleau-Petit, D.; D'Ari, R. Escherichia coli physiology in Luria-Bertani broth. J. Bacteriology 2007, 189, 8746-8749.

17. Magalia, S.; Camero, T. Susceptibilidad de Candida albicans 'invitro' mediante los pozos de difusión. Bolet'in Venezolanode Infectolog'ia 1997, 7, 5-8.

18. Magaldi, S.; Camero, T.; Mata, S.; Ortigoza-Medrano, E.; Arroyo-Espinosa, D.I. Pruebas de sensibilidadde Candida albicansfrente a los de usocomercial. Bolet'in Sociedad Venezolana de Microbiologia 1998, 18, 16-20.

19. Magaldi S.; Mata, S.; Camero, T.; Marcano, C.; Hartung, C. Determinación de lasensibilidadantifúngica en agentes de cromoMICosismediantelatécnica de los pozos de difusión. Antibióticos e Infección 1999, 7, 17-20.

20. Magaldi, S.; Mata, S.; Hartung, C.; Verde, G.; Deibis, L.; Roldín, Marcano, Y. 'In vitro' susceptibility of 137 Candida sp. isolates from HIV positive patients to several antifungal drugs. Mycopathologia 2000, 149, 63-68.

21. Magaldi, S.; Rios, A.; Hartung, C.; Verde, G.; Spencer, L.; Mata, S. In vitro susceptibilityto fluconazole of Candida spp. isolates comparing three different methods. J. Mycol. Med. 2001, 11, 123-126. 